\title{
An Analysis of Elementary Schools Teachers' Classroom Control Levels ${ }^{\mathrm{i}}$
}

\author{
Z. Nalan Yilmaz ${ }^{1, *}$, Ali E. Sahin ${ }^{2}$ \\ ${ }^{1}$ Department of Elementary Education, Faculty of Education, Hakkari University, Turkey \\ ${ }^{2}$ Department of Elementary Education, Faculty of Education, Hacettepe University, Turkey
}

Copyright $\mathrm{O} 2016$ by authors, all rights reserved. Authors agree that this article remains permanently open access under the terms of the Creative Commons Attribution License 4.0 International License

\begin{abstract}
The data of this study, that aims to develop an effective and reliable measuring instrument and to determine the relation between various variables and teachers practicing their profession at elementary schools, are obtained through the contribution of class and subject area teachers who worked during the school year of 2011-2012 in elementary schools located in Hakkari city center. As a result of the study, it is revealed that elementary school teachers, in general, adopt the approach of medium-level control. It is one of the results obtained from the study that female teachers do not establish a strict control over their students and have the tendency to share the responsibility of educational activities with them. As elementary school teachers' practices were analyzed regarding the control approaches they adopted, the results indicate that visual arts teachers along with foreign language teachers and classroom teachers demonstrate an approach of lower control-level in their classes.
\end{abstract}

Keywords Classroom Management, Teacher Control Level, Discipline Models

\section{Introduction}

The majority of the teaching-learning activities take part in classrooms. Achieving the goals of the activities conducted in classrooms is closely related to effective classroom management. It is known that it is the responsibility of teachers to make behaviour of students consistent with the goals of courses and to organize the learning experiences (Basar, 2009). The most intense communication in the teaching process is between teacher and students. Good relations between teacher and students faciliate forming of positive classroom environment. Such relations also simulate student interest and motivation to effectively take part in class activities. Contemporary approaches towards classroom management do not encourage teachers to establish an authority in classroom, but support democratic relations. In addition, positive communication between teacher and students improves the desired behaviour on part of students.

The first and basic step in educational management is classroom management. Classroom management can be defined as an effective and productive management of the resources, people and time in the context of classroom to achieve educational goals (Ilgar, 2005). Doyle (1985) describes classroom management as the establishment and maintenance of student cooperation in the classroom activities within a predetermined period of time (cited in Acikgoz, 2007). On the other hand, classroom management is a process. Turan (2006) defined this process as the establishment of classroom activities in a learning-centered manner and as a guidance for student behaviour.

The concept of discipline, in daily use, refers to tight order. In the field of education this concepts was defined as all of the steps to make people compatible with the views and behaviours of the group they belong (Oguzkan, 1974). The concept of discipline is a significant factor in establishing effective learning environments. On the other hand, the concepts of classroom management and discipline have been used interchangebly. However, there are some important differences between them. Discipline in the context of classroom refers to the rules and norms describing the behaviours which are expected from students and its goal is to make the students following the classroom rules. Classroom management, on the other hand, is an umbrella term which is defined as teachers' attempts to manage student behaviour, social interaction and those classroom activities which involve learning (Martin, Yin and Baldwin, 1998; cited in Sagnak, 2008).

Teachers' classroom management behaviour should be based on a scientific basis (Celik, 2008). The models on classroom management and discipline have been categorized into three sub-groups based on their underlying philosophical and psychological assumptions (Burden, 2006; Wolfgang, 1999). These are given as follows: lower level of control (guidance-based model), medium level of control 
(mutual interaction model) and higher level of control (intervention-based model). The control level adopted by teachers is important in establishing, maintaining and restoring order in the classroom (Burden, 2006). It is argued that the control approach adopted by teachers is effective and contributes to the working of schools as much as it has philosophical basis and is used in a consistent way (Sahin, 2012).

Teachers respond differently to the events occurred in classrooms. In fact, these responses are formed based on their control approach. There are various studies dealing with the basis for teacher behaviours in the process of classroom management. For this aim, the Pupil Control Ideology (PCI) (Willower, Eidell and Hoy, 1967) was developed. Later Glickman and Tamashiro (1980) developed the Belief of Discipline Inventory (BDI) to measure individuals' beliefs about discipline. Based on the BDI other scales such as the ICSM, ABCC and BIMS were developed and used by many researchers. In Turkey no such scale was developed to identify the control levels adopted by teachers. Therefore, this study aims at filling this gap, developing a valid and reliable scale.

Teachers' control approaches determine the roles of teachers and students in classroom management. In the process of classroom management not only teachers' duties and responsibilities in class but also the student roles assigned by the teachers are significant. Given that teachers' style of controlling the classroom management process is important in having effective teaching-learning environment, it should be studied. The major research question to be answered in the study is as follows: "Is the control approach adopted by teachers related to different variables?" The sub-research questions developed are as follows:

- At which level the participants use control in the process of classroom management?

- Is there any significant difference between the control level adopted by teachers and their gender and age?

- Is there any significant difference between the control level adopted by teachers and their professional experience?

- Is there any significant difference between the control level adopted by teachers and classroom size?

- Is there any significant difference between the control level adopted by teachers and their teaching field?

- Is there any significant difference between the control level adopted by teachers and grade level they teach?

\section{Method}

This study is designed based on the descriptive and causal-comparative research methods. In the descriptive side of the study, the control levels adopted by teachers are described. In the causal comparative side, the control levels are contrasted based on some variables (Gay and Airasian, 2000). The participants of the study were 301 classroom and subject area teachers working in eighteen different basic education schools in the Hakkari province.

The data of the study were collected during the school year of 2011-2012 through personal information form and the "scale for identifying control levels (SCIL)". Preparation of the scale which was used for determining the level of teachers' control was initiated by scanning the related literature. Classroom observations were made in different schools and case studies of the monitored conditions were designed by researchers. In order to determine teachers' interventions in the cases created, interviews with teachers who were not included in the survey universe were made. Listed notes taken from observations and interviews and scale items were drafted. Items based on the theoretical foundation have been studied and a scale consisting of 30 items was prepared to seek expert opinion.

For the content validity of the scale, 30 experts who work in the area of classroom management from different universities and teach classroom management courses, were consulted. A total of 60 expressions from cases reflecting the two separate control levels for each item were given in the scale and submitted for expert opinion. Responses of the scale items were "forced choice" type. These statements were distributed equally among three control levels. Taking into account suggestions from experts, corrections were made on the scale and forms were submitted to the second expert opinion. "Scale for identifying control levels" were arranged in accordance with the views and suggestions from experts and a trial form was prepared. After analyzing the answers of teachers to trials form, 21 items and 42 related statements were retained in the scale. SICL, contains three subscales representing the low, medium and highest level of control. From each subscale, it is possible to obtain a score which range from zero to 14 . The highest scored subscales represent the dominant approach of control.

This study has been contributed by 301 teachers and 296 of them completely and properly answered the items. These data were coded and statistically analysed. In the statistical analysis, the SPSS 16.0 was used. Descriptive statistics including frequency and percentage was used to analyse the data obtained from the personal information form. In order to test the correlation between the control level adopted by the teachers and the variables of the study t-test was used for comparisons with two variables. In the comparisons with more than two variables one-way variance analysis (ANOVA) was employed. For all statistical analysis the significance level was set at .05 . It cannot be expected that the classroom management style of teachers should reflect only one of three control level approaches. In the process of classroom management, teachers may employ activities which reflect all three control levels (Glickman and Tamashiro, 1980). Therefore, in the scale all three control levels are covered in sub-scales.

\section{Results and Discussion}

Table 1 shows the frequency and percentage of the data 
obtained through the personal information form.

As can be seen in Table 1 nearly half of the participants were male. Concerning the age range of the participants it was found that the majority of the participants were in the age range of 20-24. In the age range of 30 or more there were less participants. In terms of teaching experience nearly $15 \%$ of the participants were found to have five or more years of teaching experience. However, more than $80 \%$ of the particpants had only one- or four-year teaching experience. Therefore, most of the participants were newly graduated teachers. It is found that the class size the participants taught were mostly between 25 to 30 students. It is also found that there were few classrooms with 37 or more students. Regarding the teaching field of the participants it is found that nearly $80 \%$ of the participants were classroom teachers. It is also found that the distribution of the participants was nearly equal in terms of the grade level they taught.

Table 1. Demographical characteristics of the primary school teachers

\begin{tabular}{|c|c|c|c|c|}
\hline \multicolumn{2}{|c|}{ Variables } & $\mathrm{f}$ & $\%$ & Total \\
\hline Gender & $\begin{array}{l}\text { Female } \\
\text { Male }\end{array}$ & $\begin{array}{l}152 \\
144\end{array}$ & $\begin{array}{l}51.4 \\
48.6\end{array}$ & 296 \\
\hline Age & $\begin{array}{c}20-24 \\
25-29 \\
30 \text { and over }\end{array}$ & $\begin{array}{c}69 \\
177 \\
40\end{array}$ & $\begin{array}{l}23.3 \\
59.8 \\
16.9\end{array}$ & 296 \\
\hline $\begin{array}{l}\text { Professional } \\
\text { experience }\end{array}$ & $\begin{array}{c}\text { Less than } 1 \text { year } \\
1-4 \text { year } \\
5 \text { year and over }\end{array}$ & $\begin{array}{c}125 \\
128 \\
43\end{array}$ & $\begin{array}{l}42.2 \\
43.2 \\
14.5\end{array}$ & 296 \\
\hline Class size & $\begin{array}{c}\text { 18-24 students } \\
25-30 \text { students } \\
31-36 \text { students } \\
37 \text { and over students }\end{array}$ & $\begin{array}{c}64 \\
120 \\
84 \\
28\end{array}$ & $\begin{array}{c}21.6 \\
40.5 \\
28.4 \\
9.5\end{array}$ & 296 \\
\hline Teaching fields & $\begin{array}{l}\text { Classroom teacher } \\
\text { Foreign language } \\
\text { teacher Visual arts } \\
\text { teacher } \\
\text { Physical education } \\
\text { teacher Religious } \\
\text { studies teacher Other }\end{array}$ & $\begin{array}{c}230 \\
19 \\
10 \\
14 \\
10 \\
13\end{array}$ & $\begin{array}{l}77.7 \\
6.4 \\
3.4 \\
4.7 \\
3.4 \\
4.4\end{array}$ & 296 \\
\hline Grade level & $\begin{array}{l}\text { First grade teacher } \\
\text { Second grade teacher } \\
\text { Third grade teacher } \\
\text { Fourth grade teacher } \\
\text { Fifth grade teacher } \\
\text { Branch teacher }\end{array}$ & $\begin{array}{l}48 \\
45 \\
44 \\
47 \\
46 \\
66\end{array}$ & $\begin{array}{l}16.2 \\
15.2 \\
14.9 \\
15.9 \\
15.5 \\
22.3\end{array}$ & 296 \\
\hline
\end{tabular}

\subsection{Control Levels of Teachers in Their Classrooms}

Table 2 shows the data about the control level employed by basic education teachers. As can be seen in the table, $25,7 \%$ of them used lower level of control, $58.8 \%$ medium level of control and $15.5 \%$ higher level of control. Therefore, the dominant control level among the participants is the medium level. It is thought that it is a result of the changing educational programs. The finding that more than half of the participants used the medium level of control was also found in other studies (Bailey and Johnson, 1999; Onwuegbuzie, Witcher et. al., 2000; Sahin, 2012). However, there are other studies of which findings contradict with the current finding.
For instance, Akbaba and Altun (1998) and Kadak (2008) concluded that more than the half of the participants employed higher levels of control and that the second dominant control level was lower level of control.

Table 2. Control levels used by the teachers

\begin{tabular}{|c|c|c|c|c|}
\hline Control level & F & $\%$ & X & sd \\
\hline Lower Level of Control & 76 & 25.7 & 7.10 & 1.83 \\
\hline Medium Level of Control & 174 & 58.8 & 8.36 & 1.65 \\
\hline Higher Level of Control & 46 & 15.5 & 5.54 & 2.01 \\
\hline Total & 296 & 100 & & \\
\hline
\end{tabular}

\subsection{Control Levels of Teachers According to Their Gender and Age}

As stated earlier the difference between control levels used by the participants and their gender and age was analyzed.

As Table 3 indicates the mean scores of the participants who adopted medium level of control do not significantly vary based on gender. However, gender is found to have a significant effect on the mean scores of the participants who adopted lower and higher level of control. More specifically, female teachers who used lower level of control had higher mean scores than male teachers who used lower level of control and male teachers who used higher level of control had higher mean scores than female teachers who used higher level of control. Martin and Yin (1997) in their study on 282 teachers concluded that male teachers more frequently used intervention-based form of control in contrast to female teachers. This finding seems to support the current finding. However, in the studies by Celep (2000), Martin, Yin and Mayall (2006) and Sahin (2012) an opposite finding was found and these studies concluded that female teachers used higher levels of control in contrast to male teachers. On the other hand, there are studies which concluded that gender does not have any statistically significant effect on the control levels adopted by teachers (Obwuegbuzie, Witcher et. al., 2000; Martin et. al.,1997).

Table 3. Results of t-test on the mean difference between control levels and gender

\begin{tabular}{|c|c|c|c|c|c|c|}
\hline Subscales & Gender & $\mathrm{N}$ & $X$ & sd & $\mathrm{t}$ & $\begin{array}{c}\text { Sig. } \\
\text { (2-tailed) }\end{array}$ \\
\hline \multirow{2}{*}{$\begin{array}{c}\begin{array}{c}\text { Lower Level } \\
\text { of Control }\end{array} \\
\end{array}$} & Female & 152 & 7.41 & 1.87 & \multirow{2}{*}{3.07} & \multirow{2}{*}{0.00} \\
\hline & Male & 144 & 6.77 & 1.72 & & \\
\hline \multirow{2}{*}{$\begin{array}{l}\text { Medium } \\
\text { Level of } \\
\text { Control }\end{array}$} & Female & 152 & 8.28 & 1.66 & \multirow[b]{2}{*}{-0.80} & \multirow[b]{2}{*}{0.42} \\
\hline & Male & 144 & 8.44 & 1.65 & & \\
\hline \multirow{2}{*}{$\begin{array}{c}\text { Higher Level } \\
\text { of Control }\end{array}$} & Female & 152 & 5.30 & 1.95 & \multirow{2}{*}{-2.09} & \multirow{2}{*}{0.04} \\
\hline & Male & 144 & 5.79 & 2.05 & & \\
\hline
\end{tabular}

The mean difference is significant at the 0.05 level.

As can be seen in Table 4, the control levels adopted by teachers do not significantly vary based on their age. This finding is parallel to that of Sahin (2012). However, Celep (2000) found a significant effect of age on the control levels adopted by teachers. More specifically, it was found that older teachers tended to adopt a rule-based level of control. 
Table 4. Results of ANOVA on the mean difference between control levels and age

\begin{tabular}{|c|c|c|c|c|c|c|c|c|c|c|}
\hline & & $\mathbf{N}$ & $\Sigma \mathbf{x}$ & sd & Source of variance & $\begin{array}{l}\text { Sum of } \\
\text { squares }\end{array}$ & df & Mean square & $\mathbf{F}$ & Sig. \\
\hline \multirow{4}{*}{ LLC } & $20-24$ & 69 & 6.84 & 1.82 & \multirow{4}{*}{$\begin{array}{l}\text { Between groups Within } \\
\text { groups Total }\end{array}$} & \multirow{4}{*}{$\begin{array}{c}18.568 \\
968.392 \\
986.959\end{array}$} & \multirow{4}{*}{$\begin{array}{c}2 \\
293 \\
295\end{array}$} & \multirow{4}{*}{$\begin{array}{l}9.284 \\
3.305\end{array}$} & \multirow{4}{*}{2.809} & \multirow{4}{*}{0.062} \\
\hline & $25-29$ & 177 & 7.31 & 1.76 & & & & & & \\
\hline & $\geq 30$ & 40 & 6.70 & 2.15 & & & & & & \\
\hline & Total & 296 & 7.10 & 1.83 & & & & & & \\
\hline \multirow{4}{*}{ MLC } & $20-24$ & 69 & 8.45 & 1.71 & \multirow{4}{*}{$\begin{array}{l}\text { Between groups Within } \\
\text { groups Total }\end{array}$} & \multirow{4}{*}{$\begin{array}{c}1.058 \\
806.982 \\
808.041\end{array}$} & \multirow{4}{*}{$\begin{array}{c}2 \\
293 \\
295\end{array}$} & \multirow{4}{*}{$\begin{array}{l}0.529 \\
2.754\end{array}$} & \multirow{4}{*}{0.192} & \multirow{4}{*}{0.825} \\
\hline & $25-29$ & 177 & 8.31 & 1.61 & & & & & & \\
\hline & $\geq 30$ & 40 & 8.53 & 1.88 & & & & & & \\
\hline & Total & 296 & 8.36 & 1.66 & & & & & & \\
\hline \multirow{4}{*}{ HLC } & $20-24$ & 69 & 5.71 & 2.06 & \multirow{4}{*}{$\begin{array}{l}\text { Between groups Within } \\
\text { groups Total }\end{array}$} & \multirow{4}{*}{$\begin{array}{c}11.415 \\
1186.099 \\
1197.514\end{array}$} & \multirow{4}{*}{$\begin{array}{c}2 \\
293 \\
295\end{array}$} & \multirow{4}{*}{$\begin{array}{l}5.707 \\
4.048\end{array}$} & \multirow{4}{*}{1.410} & \multirow{4}{*}{0.246} \\
\hline & $25-29$ & 177 & 5.38 & 2.03 & & & & & & \\
\hline & $\geq 30$ & 40 & 5.77 & 1.85 & & & & & & \\
\hline & Total & 296 & 5.54 & 2.01 & & & & & & \\
\hline
\end{tabular}

The mean difference is significant at the 0.05 level.

Table 5. Results of ANOVA on the mean difference between control levels and professional experience

\begin{tabular}{|c|c|c|c|c|c|c|c|c|c|c|}
\hline & & $\mathbf{N}$ & $\Sigma \mathbf{x}$ & sd & $\begin{array}{l}\text { Source of } \\
\text { variance }\end{array}$ & Sum of squares & df & Mean square & $\mathbf{F}$ & Sig. \\
\hline \multirow{4}{*}{ LLC } & $<1$ year & 125 & 7.07 & 1.87 & \multirow{4}{*}{$\begin{array}{c}\text { Between groups } \\
\text { Within groups } \\
\text { Total }\end{array}$} & \multirow{4}{*}{$\begin{array}{c}0.616 \\
986.343 \\
986.959\end{array}$} & \multirow{4}{*}{$\begin{array}{c}2 \\
293 \\
295\end{array}$} & \multirow{4}{*}{$\begin{array}{l}0.308 \\
3.366\end{array}$} & \multirow{4}{*}{0.092} & \multirow{4}{*}{0.913} \\
\hline & $1-4$ year & 128 & 7.09 & 1.81 & & & & & & \\
\hline & $\geq 5$ year & 43 & 7.21 & 1.81 & & & & & & \\
\hline & Total & 296 & 7.10 & 1.83 & & & & & & \\
\hline \multirow{4}{*}{ MLC } & $<1$ year & 125 & 8.34 & 1.82 & \multirow{4}{*}{$\begin{array}{c}\text { Between groups } \\
\text { Within groups } \\
\text { Total }\end{array}$} & \multirow{4}{*}{$\begin{array}{c}1.954 \\
806.087 \\
808.041\end{array}$} & \multirow{4}{*}{$\begin{array}{c}2 \\
293 \\
295\end{array}$} & \multirow{4}{*}{$\begin{array}{l}0.977 \\
2.751\end{array}$} & \multirow{4}{*}{0.355} & \multirow{4}{*}{0.701} \\
\hline & $1-4$ year & 128 & 8.43 & 1.47 & & & & & & \\
\hline & $\geq 5$ year & 43 & 8.19 & 1.68 & & & & & & \\
\hline & Total & 296 & 8.36 & 1.66 & & & & & & \\
\hline \multirow{4}{*}{ HLC } & $<1$ year & 125 & 5.58 & 2.02 & \multirow{4}{*}{$\begin{array}{c}\text { Between groups } \\
\text { Within groups } \\
\text { Total }\end{array}$} & \multirow{4}{*}{$\begin{array}{c}0.937 \\
1196.577 \\
1197.514\end{array}$} & \multirow{4}{*}{$\begin{array}{c}2 \\
293 \\
295\end{array}$} & \multirow{4}{*}{$\begin{array}{l}0.468 \\
4.084\end{array}$} & \multirow{4}{*}{0.115} & \multirow{4}{*}{0.892} \\
\hline & $1-4$ year & 128 & 5.48 & 2.09 & & & & & & \\
\hline & $\geq 5$ year & 43 & 5.60 & 1.77 & & & & & & \\
\hline & Total & 296 & 5.54 & 2.01 & & & & & & \\
\hline
\end{tabular}

The mean difference is significant at the 0.05 level.

\subsection{Control Levels of Teachers According to Their Professional Experience}

As indicated in Table 5, the control levels adopted by teachers do not significantly vary based on their professional experience. Similarly, Unal and Unal (2009) found that novice teachers and experienced teachers have similar attitudes in regard to the control level. Rosas and West (2009) also reached a similar finding and argued that pre-service teachers and experienced teachers did not differ in terms of their beliefs about classroom management. There are also studies of which findings contradict with the current finding. For instance, Obwuegbuzie, Witcher et. al. (2000) in their study in which the BDI was used to collect data found that experienced teachers adopted higher level of control. 


\subsection{Control Levels of Teachers According to Class Size}

As can be seen in Table 6, no statistically significant difference was found between teachers' control approach and the class size they taught. However, Unal and Unal (2009) found that there is a significant difference between teachers who taught classes with less than 25 students and those who taught classes with more than 25 students in terms of their dominant control levels. They further argued that teachers who taught crowded classes frequently employ higher levels of control and therefore, intervention-based control approach.

\subsection{Control Levels of Teachers According to Teaching Fields}

Non-parametrical tests were employed to identify whether or not teaching fields of teachers have significant effects on their control levels. Given that the number of teachers per each teaching field was under thirty and that the assumptions of the ANOVA test were not met, its non-parametrical version, namely the Kruskal-Wallis test, was used. The results of this test were as follows: for lower level of control $\mathrm{X}_{(0.05,5)}^{2}=7,151, p<.05$, for medium level of control $\mathrm{X}_{(0.05,5)}^{2}=9,136, p<.05$ and for higher level of control $\mathrm{X}_{(0.05,5)}^{2}=6,931, \mathrm{p}<.05$. Given these results it is safe to argue that field of teaching does not have any significant effect on the control levels adopted by teachers. Similarly, Sahin (2012) also did not find any significant effect of teaching fields on teachers' approach towards classroom management.

\subsection{Control Levels of Teachers According to Grade Level They Teach}

As seen in Table 7, the grade level is not found to have any significant effect on the control levels adopted by the participants. However, Martin and Baldwin (1996) studied the control levels of primary teachers and secondary teachers and concluded that primary teachers adopted lower levels of control. The finding by Onwuegbuzie, Witcher et. al. (2000) supports that of Martin and Baldwin and it was concluded that secondary teachers were much more interventionist in their approach to control.

Table 6. Results of ANOVA on the mean difference between control levels and class size

\begin{tabular}{|c|c|c|c|c|c|c|c|c|c|c|}
\hline & & $\mathbf{N}$ & $\Sigma \mathbf{x}$ & sd & $\begin{array}{l}\text { Source of } \\
\text { variance }\end{array}$ & Sum of squares & df & Mean square & $\mathbf{F}$ & Sig. \\
\hline \multirow{5}{*}{ LLC } & $18-24$ & 64 & 6.66 & 1.86 & \multirow{5}{*}{$\begin{array}{c}\text { Between groups } \\
\text { Within groups } \\
\text { Total }\end{array}$} & \multirow{5}{*}{$\begin{array}{c}22.695 \\
964.265 \\
986.959\end{array}$} & \multirow{5}{*}{$\begin{array}{c}3 \\
292 \\
295\end{array}$} & \multirow{5}{*}{$\begin{array}{l}7.565 \\
3.302\end{array}$} & \multirow{5}{*}{2.291} & \multirow{5}{*}{0.078} \\
\hline & $25-30$ & 120 & 7.38 & 1.83 & & & & & & \\
\hline & $31-36$ & 84 & 7.01 & 1.66 & & & & & & \\
\hline & $\geq 37$ & 28 & 7.21 & 2.10 & & & & & & \\
\hline & Total & 296 & 7.10 & 1.83 & & & & & & \\
\hline \multirow{5}{*}{ MLC } & $18-24$ & 64 & 8.42 & 1.76 & \multirow{5}{*}{$\begin{array}{c}\text { Between groups } \\
\text { Within groups } \\
\text { Total }\end{array}$} & \multirow{5}{*}{$\begin{array}{c}1.116 \\
806.925 \\
808.041\end{array}$} & \multirow{5}{*}{$\begin{array}{c}3 \\
292 \\
295\end{array}$} & \multirow{5}{*}{$\begin{array}{l}0.372 \\
2.763\end{array}$} & \multirow{5}{*}{0.135} & \multirow{5}{*}{0.939} \\
\hline & $25-30$ & 120 & 8.29 & 1.60 & & & & & & \\
\hline & $31-36$ & 84 & 8.37 & 1.61 & & & & & & \\
\hline & $\geq 37$ & 28 & 8.46 & 1.86 & & & & & & \\
\hline & Total & 296 & 8.36 & 1.66 & & & & & & \\
\hline \multirow{5}{*}{ HLC } & $18-24$ & 64 & 5.92 & 2.19 & \multirow{5}{*}{$\begin{array}{c}\text { Between groups } \\
\text { Within groups } \\
\text { Total }\end{array}$} & \multirow{5}{*}{$\begin{array}{c}16.321 \\
1181.193 \\
1197.514\end{array}$} & \multirow{5}{*}{$\begin{array}{c}3 \\
292 \\
295\end{array}$} & \multirow{5}{*}{$\begin{array}{l}5.440 \\
4.045\end{array}$} & \multirow{5}{*}{1.345} & \multirow{5}{*}{0.260} \\
\hline & $25-30$ & 120 & 5.33 & 2.03 & & & & & & \\
\hline & $31-36$ & 84 & 5.62 & 1.91 & & & & & & \\
\hline & $\geq 37$ & 28 & 5.32 & 1.79 & & & & & & \\
\hline & Total & 296 & 5.54 & 2.01 & & & & & & \\
\hline
\end{tabular}

The mean difference is significant at the 0.05 level. 
Table 7. Results of ANOVA on the mean difference between control levels and grade level

\begin{tabular}{|c|c|c|c|c|c|c|c|c|c|c|}
\hline & & $\mathbf{N}$ & $\Sigma x$ & Sd & Source of & Sum of & df & Mean square & $\mathbf{F}$ & Sig. \\
\hline \multirow{7}{*}{ LLC } & First grade & 48 & 7.27 & 1.62 & \multirow{7}{*}{$\begin{array}{c}\text { Between groups } \\
\text { Within groups } \\
\text { Total }\end{array}$} & \multirow{7}{*}{$\begin{array}{c}11.984 \\
974.975 \\
986.959\end{array}$} & \multirow{7}{*}{$\begin{array}{c}5 \\
290 \\
295\end{array}$} & \multirow{7}{*}{$\begin{array}{l}2.397 \\
3.362\end{array}$} & \multirow{7}{*}{0.713} & \multirow{7}{*}{.614} \\
\hline & Second grade & 45 & 7.20 & 1.95 & & & & & & \\
\hline & Third grade & 44 & 6.68 & 1.71 & & & & & & \\
\hline & Fourth grade & 47 & 7.09 & 2.01 & & & & & & \\
\hline & Fifth grade & 46 & 7.00 & 1.51 & & & & & & \\
\hline & Branch & 66 & 7.27 & 2.04 & & & & & & \\
\hline & Total & $\begin{array}{c}29 \\
6 \\
\end{array}$ & 7.10 & 1.83 & & & & & & \\
\hline \multirow{7}{*}{ MLC } & First grade & 48 & 8.35 & 1.45 & \multirow{7}{*}{$\begin{array}{c}\text { Between groups } \\
\text { Within groups } \\
\text { Total }\end{array}$} & \multirow{7}{*}{$\begin{array}{c}1.023 \\
807.017 \\
808.041\end{array}$} & \multirow{7}{*}{$\begin{array}{c}5 \\
290 \\
295\end{array}$} & \multirow{7}{*}{$\begin{array}{l}0.205 \\
2.783\end{array}$} & \multirow{7}{*}{0.074} & \multirow{7}{*}{.996} \\
\hline & Second grade & 45 & 8.27 & 1.78 & & & & & & \\
\hline & Third grade & 44 & 8.48 & 1.73 & & & & & & \\
\hline & Fourth grade & 47 & 8.34 & 1.63 & & & & & & \\
\hline & Fifth grade & 46 & 8.35 & 1.40 & & & & & & \\
\hline & Branch & 66 & 8.36 & 1.88 & & & & & & \\
\hline & Total & $\begin{array}{c}29 \\
6\end{array}$ & 8.36 & 1.66 & & & & & & \\
\hline \multirow{7}{*}{ HLC } & First grade & 48 & 5.38 & 2.01 & \multirow{7}{*}{$\begin{array}{c}\text { Between groups } \\
\text { Within groups } \\
\text { Total }\end{array}$} & \multirow{7}{*}{$\begin{array}{c}7.980 \\
1189.533 \\
1197.514\end{array}$} & \multirow{7}{*}{$\begin{array}{c}5 \\
290 \\
295\end{array}$} & \multirow{7}{*}{$\begin{array}{l}1.596 \\
4.102\end{array}$} & \multirow{7}{*}{0.389} & \multirow{7}{*}{.856} \\
\hline & Second grade & 45 & 5.53 & 2.13 & & & & & & \\
\hline & Third grade & 44 & 5.84 & 1.93 & & & & & & \\
\hline & Fourth grade & 47 & 5.57 & 2.19 & & & & & & \\
\hline & Fifth grade & 46 & 5.65 & 1.66 & & & & & & \\
\hline & Branch & 66 & 5.36 & 2.13 & & & & & & \\
\hline & Total & $\begin{array}{c}29 \\
6 \\
\end{array}$ & 5.54 & 2.01 & & & & & & \\
\hline
\end{tabular}

The mean difference is significant at the 0.05 level.

\section{Conclusion and Suggestions}

In the study a valid and reliable data collection tool was developed to identify the level of control adopted by teachers. Of the 296 participants, twenty-four teachers were selected and grouped into three subgroups to conduct focus group interviews. The data obtained from the interviews were compared with their answers to the scale. The comparison yielded a significant correlation between these two types of data $(r=0.677, p<.0001)$. This finding shows that the scale developed is an effective data collection tool on the subject.

In the study the control approach adopted by basic education teachers was identified. It was found that their control approach do not significantly vary based on their gender, age, professional experience, class size they taught, their teaching field and grade level. The major findings reached in the study are briefly given as follows:

- In general basic education teachers adopted medium level of control. This finding is supported by previous findings (Bailey and Johnson, 1999; Onwuegbuzie, Witcher et. al., 2000; Sahin, 2012). The reason for adopting a medium level of control seems to be related to the education of these teachers. It can be argued that course contents in the teacher training programs which are determined by the Turkish Higher Education Council produce a homogenous group of teachers. The other reason seems to be the approach of school administration which encourages the adoption of medium levels of control by teachers.

- It was found that gender has a significant correlation with the control levels of teachers. This effect was observed in both higher level of control and lower level of control. Martin and Yin (1997) also reached a similar finding. Female teachers are thought to employ either lower or medium levels of control due to the fact that higher level of control is not accepted by the school administration. It can be argued that school administration and parents can more easily affect their behaviour. Unlike the present findings Celep (2000), Martin, Yin and Mayall (2006) and Sahin (2012) found that female teachers used higher level of control in contrast to male teachers.

- It is also found that the age, professional experience of the participants and the class size they taught do not have any significant effect on the control levels used by them. Sahin (2012) also concluded that there is no significant correlation between teachers' control levels and their age. Similar findings were reached by Rosas and West (2009) and Unal and Unal (2009) and they found that there is no significant correlation between teachers' control levels and their professional experience. Novice teachers seem to develop a 
discipline model based on their undergraduate education and to use those activities reflecting their model of discipline. However, this model may change in parallel to their teaching experience. In other cases, class size may also affect the control models employed by teachers.

- In the study it was found that teaching field of teachers does not have any significant effect on the control models of teachers. Although, this relationship was not frequently analyzed, Sahin (2012) examined the effects of teaching field of teachers on their control models. However, Şahin did not find any significant difference between control levels of teacher and their field of teaching, supporting the current finding.

- The other major finding of the study is that grade level does not have any significant effect on the control models of teachers. It may stem from the fact that the majority of the participants are novice teachers or that they were not very familiar with their students due to frequent change of their working schools.

There are studies dealing with the analysis of the control levels and classroom management approach of teachers based on certain variables. However, the factors affecting teachers' control levels and the effects of teachers' control levels have not been frequently studied. Therefore, future studies may deal with the effects of teachers' control levels on student achievement. In addition, in-classroom observations and interviews with teachers should be employed to gather data in such studies to connect the beliefs of teachers about their control level and classroom management activities. Another possible study topic can be the differences among teachers working at public schools and at private schools in terms of their control levels. The views of school administrators, parents and students about the control levels of teachers may also be studied.

Research findings indicate that the levels of control used by teachers are equal. However, the level of control and the discipline approach adopted by them are significant in their teaching activities. If teachers are aware of the philosophy underlying the level of control they use and if they internalize it, these affect their teaching behavior. The level of control constitutes the consistency in their classroom management and discipline-related behavior. Therefore, teachers may become informed about their control approach and may follow studies in this regard.

School administrators have certain roles in facilitating the student learning and providing proper learning environment in schools. Teachers should be given an opportunity to follow changing educational points. Educational administrators may organize in-service training about the discipline-related topics and discipline activities. Teachers may also encourage teachers to employ their level of control in their teaching activities.

There are other related dimensions which can be carried out by teacher-training institutions. In order to enable pre-service teachers to make informed choices over the discipline model to adopt they should learn well about the theories and philosophy underlying the control levels in their training program. The undergraduate course on classroom management offered to pre-service teachers is an obligatory course in the teacher training programs in Turkey. This course covers all related theories and discipline models. Given that the discipline approach adopted by novice teachers will affect their activities in classrooms this course should be carefully designed and delivered. In addition, pre-service teachers may be given opportunities to practice their theoretical discipline-related knowledge and skills.

\section{REFERENCES}

[1] Açıkgöz Ün, K. (2007). Etkili Öğrenme ve Öğretme. Biliş Özel Eğitim Danışmanlık Yayınları, İzmir.

[2] Akbaba, S. ve Altun, A. (1998). Teachers' Reflections on Classroom Management. Reports-Research (143). ERIC 425148 .

[3] Bailey, G. ve Johnson, B. (2008). Preservice Teachers' Beliefs about Discipline Before and After Student Teaching. University of South Carolina, Upstate http://www.uscupstate .edu/academics/education/issues/bailey.johnson.

[4] Başar, H. (2009). Sınıf Yönetimi. Anı Yayıncılık, Ankara.

[5] Burden, P. R. (2006). Classroom Management Creating a Successful K-12 Learning Community. John Wiley \& Sons, Inc.

[6] Celep, C. (2000). The Correlation of the Factors: The Prospective Teachers' Sense Of Efficacy And Beliefs, And Attitudes About Student Control. Reports-Research (143). ERIC 451157.

[7] Çelik, V. (2008). Sınıf Yönetimi. Nobel Yayınları, Ankara.

[8] Gay, L. R. ve Airasian P. (2000). Educational Research. Competencies for Analysis and Application. Prentice-Hall, Inc.

[9] Glickman, C. D. ve Tamashiro, R. T. (1980). Clarifying Teachers' Beliefs about Discipline. Educational Leadership, 37 (6):459-464.

[10] İlgar, L. (2005). Eğitim Yönetimi Okul Yönetimi Sınıf Yönetimi. Beta Basım Yayım Dağıtım, İstanbul.

[11] Kadak, Z. (2008). İlköğretim Okullarında Görev Yapan Öğretmenlerin Liderlik Stilleri ile Sınıf Yönetimi Arasındaki İlişkinin İncelenmesi. Yayınlanmamış Yüksek Lisans Tezi. Yeditepe Üniversitesi, Sosyal Bilimler Enstitüsü, Eğitim Yönetimi ve Denetimi Yüksek Lisans Programı, İstanbul.

[12] Martin, N. K. ve Baldwin, B. (1996). Perspectives Regarding Classroom Management Style: Differences between Elementary and Secondary Level Teachers. Paper presented at the annual meeting of the Southwest Educational Research Association. New Orleans, LA. ERIC 393835.

[13] Martin, N. K. ve Yin, Z. (1997). Attitudes and Beliefs 
Regarding Classroom Management Style: Differences Between Male and Female Teachers. Paper presented at the annual meeting of the Southwest Educational Research Association. Austin, TX. ERIC 404738.

[14] Martin, N. K., Yin, Z. ve Baldwin, B. (1997). Beliefs Regarding Classroom Management Style: Differences between Male and Female, Urban and Rural Secondary Level Teachers. Paper presented at the annual meeting of the American Educational Research Association. Chicago, IL. ERIC 408136.

[15] Martin, N. K., Yin, Z. ve Mayall, H. (2006). Classroom Management Training, Teaching Experience and Gender: Do These Variables Impact Teachers' Attitudes and Beliefs Toward Classroom Management Style? Paper presented at the annual meeting of the Southwest Educational Research Association. Austin, TX. ERIC 494050.

[16] Oğuzkan, A. F. (1974). Eğitim Terimleri Sözlüğü. Türk Dil Kurumu Yayınları, Ankara.

[17] Onwuegbuzie, A. J., Witcher, A. E., Filer, J. ve Downing, J. (2000). Factors Associated with Teachers' Beliefs on Discipline. Paper presented at the annual meeting of the Mid-South Educational Research Association.
Lexington,Kentucky. ERIC 450080.

[18] Rosas, C. ve West, M. (2009). Teachers Beliefs About Classroom Management: Pre-service and Inservice Teachers' Beliefs about Classroom Management. International Journal of Applied Educational Studies, 5 (1):54-61.

[19] Sağnak, M. (2008). Liselerde Çalışan Öğretmenlerin Kullandıkları Disiplin Stilleri. Ahi Evran Üniversitesi, Kırşehir Eğitim Fakültesi Dergisi, 9 (2):17-22.

[20] Şahin, A. E. (2012). İlköğretim Öğretmenlerinin Sınıf Yönetimi Yaklaşımları. CITO Eğitim: Kuram ve Uygulama Dergisi, Nisan-Haziran, (16): 22-28.

[21] Turan, S. (2006). Sınıf Yönetiminin Temelleri. Sınıf Yönetimi Şişman, M. ve Turan S. (Editörler). PegamA Yayınları, Ankara.

[22] Ünal, Z. Ve Ünal, A. (2009). Comparing Beginning and Experienced Teachers' Perceptions of Classroom Management Beliefs and Practices in Elementary Schools in Turkey. The Educational Forum, 73 (3):256-270.

[23] Wolfgang, C. H. (1999). Solving Discipline Problems. John Wiley \& Sons, Inc.

\footnotetext{
${ }^{i}$ It is a part of the doctoral thesis which was approved on 28 December 2012 by Institute of Social Sciences,Hacettepe University, Turkey.
} 